\title{
Reading through the Lens of Diversity: Responses, Practices, Traditions
}

\author{
Vanessa Irvin, Guest Editor \\ Keywords: diversity; editorial; librarianship; reading; response
}

Publication Type: editorial

\section{Editorial}

\begin{abstract}
A
$\mathrm{n}$ inseparable part of the universal journey of life is the experience of "reading the world" (Freire \& Macedo, 1987, p. 50). Our worlds are full of meaning and significance for all of us. Feeling, responding, and reflecting on an experience typically beg us, as human beings, to record it, to connect the past and the present as a way of sustaining memory, which then allows us to anticipate the future. Recorded memory is an inheritance of sorts, for our families, neighbors, and even strangers. Cultural record, based on unique ways of living and doing, can come in a myriad of formats: print, electronic, and oral; as objects of nature and as images of the body.
\end{abstract}

While honoring the theme of this special issue, an ongoing question for me, as guest editor, was: What does it mean to put the concepts of reading and diversity together in the context of librarianship and information disciplines and practices? Are we talking about diverse perspectives on the practice of reading, or are we approaching the idea of reading through the lens of diverse life experiences and perceptions of the world? The articles in this issue cover a spectrum of ways that reflect the idea of diversity and reading in library and information spaces, in community spaces, and also in our personal and spiritual spaces, both visible and unseen.

When we think about diversity, the concept that parallels it is the notion of multiplicity: When we are talking about diversity, we are talking about multiplicity. Thus, this issue's theme, "Diversity \& Reading," is expressed in a cluster of papers that regard reading as a multiplicity of the human experience: the reading of the self, the reading of readers, librarians as readers and facilitators of the reading experience, and the reading of the body embedded in various spaces and time in continuums of history/heritage. This vision gives new meaning to the idea of record, extending it from the habitual Western manifestations of records (texts, books) to broader cultural expressions (weave patterns, tattoos, artifacts) where communities connect social acts and social life to the practice of reading. As a result, this issue combines research articles and experience-based pieces that underscore the multiplicity of the human experience that librarians and information professionals should consider in the context of reading practices in various settings.

The issue opens with the research article by Denice Adkins, Jenny Bossaller, and Heather Moulaison-Sandy, which explores a method that librarians can employ in order to learn from readers' book reviews of multicultural literature; this method enables librarians to describe and

The International Journal of Information, Diversity, \& Inclusion, 3(2), 2018

ISSN 2574-3430, jps.library.utoronto.ca/index.php/ijidi/index

DOI: $10.33137 /$ ijidi.v3i2.32590 
categorize multicultural fiction more accurately and authentically. Their methodology of text mining of reader book reviews from Amazon.com helps to record and document collective consciousness that readers develop through reading. The authors then consider how readergenerated metadata can help librarians make more meaningful professional choices. This study demonstrates the effectiveness of in-depth engagement with readers' responses in a digital environment for gaining insight into what readers commonly see, question, and enjoy in the process of reading.

While the first article of the issue considers how librarians can incorporate reading preferences into the selection of library materials, Emily Knox's article takes a look at the ways in which readers convey their dislikes and objections; stories presented in fiction and nonfiction books transcend printed pages and challenge readers' beliefs and established values. Knox calls on us to consider what "people [are] reading into diverse/multicultural books" and to recognize the multiplicity of reader responses, or outcomes of reading. These outcomes can range from blissful responses (Sumara, 1996) to book banning and censorship, as Knox argues.

Sarah Evans looks at the reading practices of immigrant teens who frequent a public library to illustrate the multiple ways in which library staff can promote and support reading practices of newly arrived readers. Evans' research encourages us to view library practitioners as intellectually curious, caring, and empathetic professionals who can engage readers through participation, not prescriptive actions.

Research articles are followed by the special section titled "Around the World: Information, Spirituality, Culture." It features M. Elena Clariza's piece, which reflects the inclusive and expanded definition of reading as a practice that can occur in a multiplicity of forms and contexts. Clariza's paper focuses on the embodiment of reading in Filipino culture, and reading as an interactive and iterative practice that derives from multiple aspects of the lived experience, traditions, and ancestral knowledge. In her beautifully illustrated article, Clariza discusses two indigenous traditions from the Philippines-body tattooing and fabric weaving-that constitute indigenous authentic, historical, and holistic forms of reading. Clariza sheds light on the multiplicity of ways in which reading is honored, sustained, and preserved in indigenous cultures as both utilitarian and sacred. By doing so, the author takes steps toward decolonizing our perceptions of reading practices and urges us to recognize and legitimize recorded experiences in multiple forms, beyond textual symbols.

In the "Reports from the Field" section, we have two articles that report on the reading practices from formal and informal spaces. Valerie Brett Shaindlin argues that cultural heritage institutions (e.g., archives and museums) are "identity-generating institutions that both preserve and perpetuate ideology and culture." Shaindlin then ponders: whose identity? whose ideology? whose culture? The author goes on to explore a differentiation between modern and post-modern museums, reminding archivists and information professionals of the importance of embracing equitable models of presenting artifacts and developing programs.

In turn, Ellen Gilbert reports on a community-based reading program that has been engaging community members through the discursive and transformative process. The People \& Stories / Gente y Cuentos project has had a positive impact on immigrants in New Jersey for decades. The program honors the orality of Caribbean Spanish culture alongside the group-oriented reading of texts in Spanish and then in English, to facilitate language learning. Gilbert's piece proves that the collective act of reading is a powerful model in community building and relationship

The International Journal of Information, Diversity, \& Inclusion, 3(2), 2018

ISSN 2574-3430, jps.library.utoronto.ca/index.php/ijidi/index

DOI: $10.33137 /$ ijidi.v3i2.32590 
development.

It is my hope that this special issue is regarded as a meaningful contribution to the ongoing discourse in library and information science (LIS) that allow us to continue being comprehensive in our definitions, conceptualizations, and experiences related to reading practices, diversity of literatures and traditions, identities of readers, and reflections on library services. The research herein represents an encouraging record that underscores the strength of LIS as a field that is theoretically framed to be responsive to community needs, reflective about librarian professional practices, innovative in library services, and inclusive of reading traditions across the world. Lifelong learning extending beyond academia and classroom into the wider world may be one of our profession's hallmarks, but it is also our professional responsibility. In this vein, I hope that publications presented herein inspire us to continuously embrace the diversity of reading in practice, research, and tradition.

\section{References}

Freire, P., \& Macedo, D. (1987). Literacy: Reading the word and the world. New York, NY: Bergin \& Garvey.

Sumara, D. J. (1996). Private readings in public: Schooling the literary imagination. New York, NY: Peter Lang.

Vanessa Irvin (irvinv@hawaii.edu) is an assistant professor of library and information science (LIS) with the University of Hawai'i-Mānoa's LIS Program. Dr. Irvin is a career-public librarian who has transitioned into scholarly research, focusing on cultural competency in public librarianship. As principal investigator of a three-year Institute of Museum and Library Services funded program, Irvin is working with professionals and cultural practitioners from Hui 'Ekolu ("three groups" in Hawaiian): the Native Hawaiian Library, the Hawai'i State Public Library System, and the University of Hawai' $i$ LIS Program, to devise and implement a culturally-centered professional development model for public librarians serving in libraries located in indigenous and native contexts.

The International Journal of Information, Diversity, \& Inclusion, 3(2), 2018

ISSN 2574-3430, jps.library.utoronto.ca/index.php/ijidi/index

DOI: $10.33137 /$ ijidi.v3i2.32590 